\title{
PERAN KEPEMIMPINAN TRANSFORMASIONAL DAN JENIS KELAMIN TERHADAP KETERIKATAN KERJA
}

\author{
Dian Ardianti ${ }^{1}$, Fransisca I. R. Dewi ${ }^{2}$, P. Tommy Y.S. Suyasa ${ }^{3}$ \\ ${ }^{1}$ Program Studi Magister Psikologi, Universitas Tarumanagara, Jakarta \\ Email: dian.707199102@stu.untar.ac.id \\ ${ }^{2}$ Fakultas Psikologi, Universitas Tarumanagara, Jakarta \\ Email: fransiscar@fpsi.untar.ac.id \\ ${ }^{3}$ Fakultas Psikologi, Universitas Tarumanagara, Jakarta \\ Email:tommys@fpsi.untar.ac.id
}

Masuk : 30-03-2020, revisi: 25-10-2020, diterima untuk diterbitkan : 31-10-2020

\begin{abstract}
According to the literature, employees who have vigor, dedication and absorp in their work are considered to have a high work engagement and are able to increase productivity. This research was conducted to see the role of transformational leadership and gender to work engagement. Participants are 208 IT sales that sell IT products. The instrument test uses item analysis test, and regression analysis uses multiple regression. The results show that only transformational leadership has a significant relationship with work engagement, that means the higher the role of transformational leaders, the higher level of work engagement is held. While the gender variable does not have a significant relationship with work engagement. Based on the results obtained, the role of transformational leadership is needed by IT sales as a factor that can increase work engagement.
\end{abstract}

Keywords: work engagement, transformational leadership, gender

\begin{abstract}
ABSTRAK
Menurut literatur, karyawan yang menampilkan semangat, dedikasi dan tenggelam dalam pekerjaan mereka dianggap memiliki keterikatan kerja yang tinggi serta mampu meningkatkan produktivitas. Penelitian ini dilakukan untuk melihat peran kepemimpinan transformasional dan jenis terhadap keterikatan kerja. Partisipan berjumlah 208 sales IT yang melakukan penjualan produk IT. Uji instrumen menggunakan uji analisis butir, serta analisis regresi menggunakan regresi berganda. Hasil menunjukkan bahwa hanya kepemimpinan transformasional yang berperan secara signifikan terhadap keterikatan kerja, artinya semakin tinggi peran pemimpin transformasional yang dirasakan maka semakin tinggi pula tingkat keterikatan kerja yang dimiliki. Sedangkan variabel jenis kelamin tidak berperan terhadap keterikatan kerja. Berdasarkan hasil yang diperoleh, peran kepemimpinan transformasional diperlukan oleh sales IT sebagai faktor yang dapat meningkatkan keterikatan kerja.
\end{abstract}

Kata Kunci: keterikatan kerja, kepemimpinan transformasional, jenis kelamin

\section{PENDAHULUAN}

PT. X merupakan perusahaan yang bergerak di bidang IT di Jakarta yang sudah berdiri sejak tahun 1998. PT. X didirikan oleh para profesional IT yang berpengalaman dan terampil yang telah melayani beberapa sektor industri selama bertahun-tahun. Namun, selama tiga tahun berturut-turut terjadi penurunan tingkat penjualan yang disebabkan oleh permasalahan pada sales perusahaan IT tersebut. Berdasarkan hasil wawancara yang didapatkan, terdapat sales yang menunjukkan perilaku tidak terikat dengan pekerjaannya.

Keberhasilan seorang sales merupakan salah satu hal yang sangat vital pada perkembangan sebuah perusahaan. Hal tersebut dapat dilihat dari kemampuan menyeimbangkan neraca aktivitas penjualannya untuk mengukur hasil yang sudah ia capai. Untuk mendukung peran sales IT, dibutuhkan pribadi yang bersemangat, berdedikasi, serta mengerjakan pekerjaannya dengan sepenuh hati. Menurut Bakker dan Demerouti (2008), karyawan yang terikat akan bekerja dengan keras dengan pikiran yang positif, maka dari itu mereka lebih cepat atau banyak menyelesaikan tugasnya di tempat kerja. 
Selama dua dekade terakhir, jumlah studi tentang keterlibatan kerja telah meningkat dengan cepat. Keterikatan kerja mengacu pada keadaan energi motivasi-afektif yang positif, dikombinasikan dengan tingkat dedikasi tinggi dan fokus yang kuat pada pekerjaan (Schaufeli \& Bakker, 2010). Karyawan yang memiliki keterikatan kerja yang tinggi, akan memiliki pengaruh yang besar terhadap pekerjaanya sehingga pada akhirnya akan menjadi sangat terikat (Yalabik, Popaitoon, Chowne, \& Rayton, 2013).

Menurut Christian, Garza, dan Slaughter (2011), kepemimpinan merupakan komponen penting yang mempengaruhi lingkungan kerja serta bagaimana karyawan memandang pekerjaan mereka. Beberapa hal yang menjadi penggerak ketidakterikatan karyawan diantaranya adalah manajemen dan kepemimpinan (McBain, 2007). Pemimpin sebuah organisasi diharapkan memiliki beberapa keterampilan diantaranya dapat menginsipirasi karyawannya untuk memiliki visi di masa depan, memberi contoh perilaku yang baik, menumbuhkan semangat bekerjasama sehingga memiliki kinerja yang tinggi, pemberian umpan balik serta menghormati dan peduli dengan perasaan dan kebutuhan pribadi karyawannya.

Berdasarkan survei terbuka terhadap beberapa orang sales, diperoleh persepsi sales terhadap pimpinannya. Menurutnya, pemimpin dirasa kurang mampu mengayomi dengan baik. Pemimpin terus menekan untuk meningkatkan target penjualan tanpa membahas secara bersama-sama tujuan organisasi dengan jelas dan terarah. Pemimpin juga dirasa kurang memberikan contoh yang baik secara konsisten yang dapat diikuti oleh sales serta kurang nampak memberikan dorongan untuk menciptakan tim kerja yang mampu bekerja sama.

Dengan dirasakannya peran pemimpin transformasional di tengah-tengah para sales, peneliti menduga akan menimbulkan rasa kepercayaan, kekaguman, kesetiaan dan hormat terhadap pemimpin tersebut sehingga mereka termotivasi untuk meningkatkan target penjualan lebih dari yang diharapkan pemimpin maupun perusahaan.

Sejalan dengan penelitian terdahulu yang dilakukan oleh Hawkes, Biggs, dan Hegerty (2017), peran perilaku kepemimpinan transformasional dapat menciptakan keterikatan kerja yang lebih tinggi. Menurut hasil penelitian tersebut, pentingnya mengembangkan pemimpin transformasional adalah salah satu metode di mana organisasi dapat memperoleh keunggulan kompetitif. Penelitian tersebut masih memiliki keterbatasan dari segi ukuran sampel yang tidak terlalu besar mengingat sampel tidak memiliki spesifikasi di satu jabatan saja.

Selain peran kepemimpinan, keberagaman dalam organisasi juga masih perlu dikaji. Peneliti menggunakan aspek keragaman jenis kelamin sales yaitu pria dan wanita untuk melihat perannya terhadap keterikatan kerja. Dukungan teoritis pada hubungan antara keanekaragaman jenis kelamin dan kinerja didasarkan pada gagasan bahwa pria dan wanita membawa sudut pandang yang berbeda, diantaranya keanekaragaman dalam kreativitas dan inovasi, memiliki wawasan pasar yang beragam, serta keterampilan yang lebih luas dalam penyelesaian masalah dan pengambilan keputusan (Farrell \& Hersch, 2001; Shrader, Blackburn, \& Iles, 1997; Smith, Smith, \& Verner, 2006; Watson, Kumar, \& Michaelsen, 1993). Penelitian telah menemukan bahwa tim yang beraneka ragam gender memiliki kinerja yang lebih baik daripada tim dengan satu jenis kelamin (Orlitzky \& Benjamin, 2003). 
Masih sedikit penelitian yang meramalkan kepemimpinan transformasional dan jenis kelamin dapat mempengaruhi keterikatan kerja. Melalui fenomena yang ada pada sales IT dalam keterikatan kerja, membuat peneliti tertarik untuk melihat peran dari kepemimpinan transformasional dan jenis kelamin terhadap keterikatan kerja.

Rumusan masalah dalam penelitian ini adalah ingin menguji apakah kepemimpinan transformasional dan jenis kelamin memiliki peran terhadap keterikatan kerja pada sales IT di PT. X.

\section{METODE PENELITIAN}

\section{Partisipan dan prosedur penelitian}

Partisipan dalam penelitian ini merupakan 208 karyawan sales IT di Jakarta. Secara spesifik, partisipan merupakan sales IT yang bekerja di perusahaan IT dan melakukan penjualan produkproduk IT, baik hardware maupun software.

Metode penelitian ini adalah kuantitatif non-eksperimental. Penelitian kuantitatif menekankan pada pengujian teori melalui pengukuran variabel penelitian dengan angka dan melakukan analisis data dengan prosedur statistika. Penelitian ini bertujuan untuk menggambarkan peran kepemimpinan transformasional dan jenis kelamin terhadap keterikatan kerja.

Pengambilan data dilakukan dengan menyebar link e-form mengenai tiga variabel tersebut dengan sampel sales di perusahaan IT di Jakarta. Pengujian hipotesis dengan pendekatan statistik menggunakan analisis regresi berganda dan diolah dengan bantuan program SPSS dan Microsoft Excel.

\section{Pengukuran}

\section{Keterikatan kerja}

Pengukuran variabel keterikatan kerja ini, peneliti mengadaptasi alat ukur the Utrecht Work Engagement Scale (UWES) yang dikembangkan oleh Schaufeli, Bakker dan Salanova (2006). Kuesioner diisi menggunakan skala untuk menilai frekuensi terjadinya butir item dengan rentang angka 0 sampai 6, di mana angka 0 memiliki arti "tidak pernah" dan angka 6 memiliki arti "selalu" atau "setiap hari". Alat ukur ini terdiri atas 17 butir soal pernyataan. Melalui hasil uji reliabilitas, diketahui bahwa keterikatan kerja memiliki koefisien alpha cronbach sebesar 0.943 $(\alpha=0.943)$. Artinya, alat ukur keterikatan kerja ini tergolong reliabel.

\section{Kepemimpinan transformasional}

Kepemimpinan transformasional diukur dengan menggunakan skala Transformational Leadership Inventory (TLI) yang diadaptasi dari skala yang disusun oleh Podsakoff (1990). Kuesioner diisi menggunakan skala untuk menilai frekuensi terjadinya butir item dengan rentang angka 1 sampai 7, di mana angka 1 memiliki arti "sangat tidak setuju" dan angka 7 memiliki arti "sangat setuju". Alat ukur ini terdiri atas 23 butir asli dan 10 butir tambahan yang dibuat oleh peneliti. Melalui hasil uji reliabilitas, diketahui bahwa keterikatan kerja memiliki koefisien alpha cronbach sebesar $0.869(\alpha=0.869)$. Artinya, alat ukur keterikatan kerja ini tergolong reliabel.

\section{HASIL DAN PEMBAHASAN}

Berdasarkan uji normalitas dengan metode kolmogorov-smirnov, variabel menunjukkan nilai signifikansi yang lebih kecil dari 0.05 , artinya dapat disimpulkan bahwa data terdistribusi tidak normal. Karena hal tersebut, peneliti melakukan uji hipotesis menggunakan teknik analisis regresi non-linear dengan menggunakan software SPSS 26. 
Selanjutnya peneliti melihat besaran $\mathrm{R}$ square untuk mengetahui berapa persen (\%) varians dependent variable yang dijelaskan oleh independent variable.

Tabel 1. Hasil R Square

\begin{tabular}{ccccc}
\hline Model & $\mathrm{R}$ & $R$ Square & Adjusted $R$ Square & Std. Error of the Estimate \\
\hline 1 & $.606^{\mathrm{a}}$ & .307 & .345 & 7.89929 \\
\hline
\end{tabular}

Dari Tabel 1 diperoleh nilai $\mathrm{R}$ sebesar 0.606 dan koefisien determinasi $\mathrm{R}^{2}$ ( $\mathrm{R}$ square) sebesar 0.307. dapat diketahui bahwa perolehan $\mathrm{R}$ square adalah sebesar 0.307 atau $30.7 \%$. Artinya adalah besarnya proposi varians dari keterikatan kerja yang dijelaskan oleh variabel kepemimpinan transformasional dan jenis kelamin adalah sebesar $36.7 \%$, sedangkan sisanya dipengaruhi oleh variabel lain diluar penelitian.

Selanjutnya, peneliti menganalisis peran dari kepemimpinan transformasional dan jenis kelamin terhadap keterikatan kerja. Adapun hasil uji hipotesis dapat dilihat pada Tabel 2 sebagai berikut:

Tabel 2. Hasil Uji Analisis

\begin{tabular}{|c|c|c|c|c|c|}
\hline \multirow{2}{*}{ Model } & \multicolumn{2}{|c|}{ Unstandardized Coefficients } & \multirow{2}{*}{$\begin{array}{c}\begin{array}{c}\text { Standardized } \\
\text { Coefficients }\end{array} \\
\text { Beta }\end{array}$} & \multirow{2}{*}{$\mathrm{t}$} & \multirow{2}{*}{ Sig. } \\
\hline & B & Std. Error & & & \\
\hline (Constant) & 9.893 & 9.374 & & 1.055 & .292 \\
\hline Kepemimpinan & .770 & .102 & .468 & 7.575 & .000 \\
\hline Transformasional & & & & & \\
\hline Jenis Kelamin & .025 & .123 & .012 & .202 & .840 \\
\hline
\end{tabular}

Berdasarkan hasil uji hipotesis diperoleh hasil bahwa nilai regresi variabel kepemimpinan transformasional terhadap keterikatan kerja dengan nilai $\beta=0.468$ dengan signifikansi $p \leq 0.05$. Hal ini menunjukkan bahwa terdapat peran kepemimpinan transformasional terhadap keterikatan kerja. Artinya, semakin dirasakannya peran pemimpin transformational, maka sales akan semakin terikat dengan pekerjaannya. Sedangkan untuk variabel jenis kelamin terhadap keterikatan kerja memperoleh nilai $\beta=0.012$ dengan signifikansi $p \geq 0.05$. Hal ini menunjukkan bahwa tidak terdapat peran jenis kelamin terhadap keterikatan kerja.

\section{KESIMPULAN DAN SARAN}

Berdasarkan hasil yang diperoleh pada penelitian ini, variabel kepemimpinan transformasional berperan secara signifikan terhadap keterikatan kerja $(\mathrm{p}=0.000)$, yang artinya semakin tinggi peran kepemimpinan transformasional yang ditunjukkan pemimpin kepada karyawannya maka semakin tinggi keterikatan kerja karyawan yang dihasilkan. Hal ini memberi informasi bahwa peran atasan lebih dimaknai oleh sales dalam melakukan pekerjaannya sehari-hari. Hasil tersebut sejalan dengan penelitian yang dilakukan oleh Hawkes, et al. (2017) dan Wailulu, et al (2019) yang menunjukkan peran perilaku kepemimpinan transformasional dapat menciptakan keterikatan kerja yang lebih tinggi.

Berbeda dengan peran kepemimpinan transformasional, variabel jenis kelamin tidak memiliki peran terhadap keterikatan kerja. Sejalan dengan penelitian Xanthopoulou, Bakker, Demerouti, dan Schaufeli (2012) yang menyatakan bahwa variabel demografi seperti jenis kelamin, usia, jabatan, tingkat pendidikan, dan status karyawan tidak memiliki peran dengan keterikatan kerja. 
Vorina, Simonic dan Vlasova (2017) juga menemukan bahwa tidak terdapat perbedaan yang signifikan dari karyawan pria maupun wanita dalam memprediksi siapakah yang lebih terikat dengan pekerjaannya.

Berbeda dengan hasil penelitian lainnya yang menyatakan bahwa karyawan wanita lebih terikat dengan pekerjaannya dibandingkan dengan karyawan pria (Akanni, 2019). Ahmed (dalam Bimantari, 2015) menemukan bahwa jenis kelamin menentukan komitmen seseorang di dalam organisasi yang nantinya akan menyebabkan keterikatan kerja seseorang. Banihani, Lewis, dan Syed (2013) menekankan perlunya untuk melakukan studi empiris lebih lanjut untuk mengeksplorasi sifat dan sejauh mana keterlibatan kerja pada gender serta implikasinya untuk karyawan pria dan wanita.

Berdasarkan hasil penelitian yang didapatkan, pihak manajemen hendaknya berupaya untuk memperhatikan keadaan perannya sebagai pemimpin yang dapat menginspirasi sales untuk mencapai target. Selain itu pemberian penghargaan kepada sales yang mencapai target penjualan hendaknya dilakukan untuk membuat para sales memiliki kewajiban untuk merespon penghargaan yang didapat dengan lebih terikat lagi dengan perusahaan. Manajemen juga hendaknya membuat pertemuan secara rutin dengan sales guna membahas permasalahan apa yang sedang terjadi di lapangan. Sehingga kemudian dapat membahas solusi serta memberikan pelatihan dan pengembangan mengenai keahlian penjualan yang mendukung pekerjaannya. Hal ini dapat mendukung tingkat keberhasilan penjualan.

\section{Ucapan Terima Kasih (Acknowledgement)}

Peneliti mengucapkan terima kasih dan apresiasi pada seluruh partisipan yang telah bersedia untuk menjadi responden pada penelitian ini.

\section{REFERENSI}

Akanni, A. (2019). Organizational climate and gender differences in work engagement among non-teaching staff in a Nigerian University. European Review of Applied Sociology, 12(19), 1-5. https://doi.org/10.1515/eras-2019-0006

Bakker, A. B., \& Demerouti, E. (2008). Towards a model of work engagement. The Journal of Career Development International, 13(3). 209-219. doi:10.1108/13620430810870476

Banihani, M, Lewis, P, and Syed, J. (2013). Is work engagement gendered?. An International Journal, 28(7), 400-423. doi:10.1108/GM-01-2013-0005

Bimantari, P. (2015). Pengaruh job demands, personal resources, dan jenis kelamin terhadap work engagement. Universitas Islam Negeri Jakarta. Skipsi.

Christian, M. S., Garza, A. S., \& Slaughter, J. E. (2011). Work engagement: A quantitative review and test of its relations with task and contextual performance. Personnel Psychology, 64(1), 89-136. doi:10.1111/j.1744-6570.2010.01203.x

Farrell, K. A., \& Hersch, P.L. (2001). Additions to corporate boards: Does gender matter? (Working Paper). Diunduh dari http://papers.ssrn.com/sol3/papers.cfm?abstract_id=292281

Hawkes, A. J., Biggs., A., \& Hegerty, E. (2017). Work engagement: Investigating the role of transformational leadership, job resources, and recovery. The Journal of Psychology, 151(6), 509-531. doi:10.1080/00223980.2017.1372339 2017

McBain, R. (2007). The practice of engagement: Research into current employee engagement practice. Strategic HR Review, 6(6), 16-19. doi:10.1108/14754390780001011 
Orlitzky, M., \& Benjamin, J. D. (2003). The effect of sex composition on small-group performance in a business school case competition. Academy of Management Learning and Education, 2(2), 128-138. doi:10.5465/AMLE.2003.9901665

Podsakoff, P. M., MacKenzie, S. B., Moorman, R. H., \& Fetter, R. (1990). Transformational leader behaviors and their effects on followers' trust in leader, satisfaction, and organizational citizenship behaviors. Leadership Quarterly, 1(2), 107-142. doi:10.1016/1048-9843(90)90009-7

Schaufeli, W., Bakker, A., \& Salanova, M. (2006). The measurement of work engagement with a short questionnaire. Educational and Psychological Measurement, 66(4), 701-716. doi:10.1177/0013164405282471

Shrader, C. B., Blackburn, V. B., \& Iles, P. (1997). Women in management and firm financial performance: An exploratory study. Journal of Managerial Issues, 9(3), 355-372. doi: $10.2307 / 40604152$

Vorina, A., Simonič, M., \& Vlasova, M. (2017). An analysis of the relationship between job satisfaction and employee engagement. Economic Themes, 55(2), 243-262. doi:10.1515/ethemes-2017-0014

Wailulu, K. N., Dewi, F. I. R., \& Idulfilastri, R. M. (2019). Peran kepemimpinan transformasional terhadap keterikatan kerja pada karyawan milenial dengan variabel komunikasi sebagai mediator. Jurnal Muara Ilmu Sosial, Humaniora, dan Seni, 3(2), 328-332. doi:10.24912/jmishumsen.v3i2.5881

Watson, W. E., Kumar K., \& Michaelsen, L. K. (1993). Cultural diversity's impact on interaction process and performance: Comparing homogeneous and diverse task groups. Academy of Management Journal, 36(3), 590-602. doi:10.5465/256593

Xanthopoulou, D., Bakker, A. B., Demerouti, E., \& Schaufeli, W. B. (2012). A diary study on the happy worker: How job resources relate to positive emotions and personal resources. European Journal of Work and Organizational Psychology, 21(4), 489-517. doi:10.1080/1359432X.2011.584386

Yalabik, Z. Y., Popaitoon, P., Chowne, J. A., \& Rayton, B. A. (2013). Work engagement as a mediator between employee attitudes and outcomes. The International Journal of Human Resource Management, 24(14), 2799-2823. doi:10.1080/09585192.2013.763844 